\title{
Biophysical properties of DNA in hydrated ionic liquids
}

\begin{abstract}
The biophysical properties and behavior of natural calf thymus DNA in hydrated 1-ethyl-3butylimidazolium bromide ionic liquid ([C2bim]Br) have been studied using spectroscopy technique. The effect of ionic liquid concentration and temperature towards the duplex BDNA conformation were determined. The presence of ionic liquid causes higher duplex DNA stability with the DNA melting temperature of $\sim 56^{\circ} \mathrm{C}$ without any addition of buffer solutions. The electrostatic attraction between ionic liquidôs cation and DNA phosphates groups was found play a main role in stabilizing native DNA structure. Understanding of the biophysical properties of DNA in this ionic media could be used as a platform for future development of specific solvent for nucleic acid nanotechnology.
\end{abstract}

Keyword: DNA; Ionic liquids; Biophysical properties; 1-ethyl-3-butylimidazolium bromide 